\title{
Działalność Państwowego Instytutu Robót Ręcznych w Warszawie w świetle protokołów rad pedagogicznych
}

\author{
Activity of the State Institute of Handicrafts \\ in Warsaw in Light of Teachers' Meeting Protocols
}

\begin{abstract}
ABSTRAKT
Jednq z zasłużonych placówek oświatowych w dziejach polskiego szkolnictwa był bez wątpienia Państwowy Instytut Robót Ręcznych, założony u progu niepodległości przez jej długoletniego dyrektora Władysława Przanowskiego. Zadaniem placówki było kształcenie przyszłych kadr nauczycielskich w zakresie nauczania robót ręcznych. Szkoła przetrwała do 1951 roku. Jej dzieje nie sq jeszcze dokładnie rozpoznane. Co prawda w 1998 roku ukazała się ksiqżka jednej z absolwentek tej placówki Eugenii Choińskiej - która we wstępie napisała, że odtworzenie dziejów szkoły, szczególnie w okresie międzywojennym jest trudne, ze względu na brak dokumentów, które uległy zniszczeniu. Tymczasem jednym z istołnych elementów do poznania historii tej placówki sq z pewnościq zachowane protokoły posiedzeń rady pedagogicznej za okres od 1928 do 1939 roku. Przechowywane sq one w archiwum w Milanówku, a ich analiza pozwala rozpoznać aktywność zarówno uczniów, jak i nauczycieli tej szkoły na arenie krajowej i międzynarodowej. Ukazuja one także organizację, problemy wychowawcze i naukowe tej placówki. Ich dokładna analiza, uzupełniona o inne źródła, może stanowić punkt wyjścia do pogłębionych badań nad dziejami tej ważnej w dziejach polskiej oświaty placówki.
\end{abstract}

SLOWA KLUCZOWE Warszawa, rada pedagogiczna, źródła, Państwowy Instytut Robót Ręcznych, II Rzeczpospolita, oświata, nauczyciele

\section{KEYWORDS}

Warsaw, teachers' council, source, State Institute of Handicrafts, the Second Polish Republic, education, teachers

SPI Vol. 19, 2016/2

ISSN 2450-5358 e-ISSN 2450-5366 DOI: 10.12775/SPI.2016.2.006 Artykuły i rozprawy 


\section{ABSTRACT}

One of the famous educational institutions in the history of Polish higher education was, without a doubt, the State Institute of Handicrafts founded just before independence by its long-term Director Vladislav Przanowski. The aim of the institution was to train the workforce of the future teachers in the field of teaching craftwork. The school existed until 1951 and its history has not yet been precisely defined. However, in 1998 a book was published by one of its graduates - Eugenia Choińska and in the introduction, the author claims that the reconstruction of the school's history, particularly in the interwar period, is difficult due to a lack of documents, which were destroyed or lost. Nevertheless, one essential factor in understanding the history of this institution is an analysis of the minutes of teachers' council meetings for the period 1928-1939. Their analysis allows the activity of both students and teachers at this school in the field of national and international activity to be determined. It also allows the reconstruction of the organization, together with the educational and research matters of this institution. Their thorough analysis, supplemented by other sources, may serve as a starting point for the in-depth research into an institution so significant in the history of the Polish education.

\section{Wprowadzenie}

W roku 1998, nakładem Instytutu Badań Edukacyjnych w Warszawie, ukazała się książka autorstwa Eugenii Choińskiej zatytułowana $Z$ dziejów ośrwiaty w Polsce. Państwowy Instytut Robót Ręcznych (1923-1950). Jest to próba odtworzenia dziejów tej liczącej się w Polsce okresu międzywojennego placówki edukacyjnej, kształcącej nauczycieli prac ręcznych, której to twórcą był Władysław Przanowski. Autorka tej książki we wstępie napisała: „Dokumentacja PIRR-u zarówno sprzed wojny, jak i z okresu powojennego zaginęła. Materiały do tej książki pochodzą z różnych publikacji, wspomnień, a nawet indeksów studenckich"1.

Powyższe stwierdzenie nie jest zgodne z prawdą, bowiem w Archiwum Dokumentacji Osobowej i Płacowej w Milanówku, stanowiącym oddział Archiwum Państwowego w Warszawie, znajduje się dość pokaźny zbiór materiałów źródłowych odnoszący się do

1 E. Choińska, Z dziejów oświaty w Polsce. Pañstwowy Instytut Robót Ręcznych (1923-1950), Warszawa 1998, s. 7. 
omawianej placówki. Wśród akt nauczycieli i uczniów zachowały się także dwa tomy protokołów rad pedagogicznych z lat 1928-1938. Wspomina o nich między innymi Wiktor Ambroziewicz, powojenny dyrektor placówki, jednakże w swojej pracy poświęconej Władysławowi Przanowskiemu nie odwołuje się do nich bezpośrednio ${ }^{2}$. Analiza zawartości tych dokumentów rzuca nowe światło na działalność tej placówki edukacyjnej.

\section{Państwowy Instytut Robót Ręcznych i jego twórca - Władysław Przanowski}

Chcąc analizować dzieje Państwowego Instytutu Robót Ręcznych, nie można tego czynić w oderwaniu od życiorysu jego twórcy, Władysława Przanowskiego. Jego biografia ściśle zazębia się z dziejami instytucji, którą bez wątpienia uznać można za dzieło jego życia. Przanowski urodził się 21 marca 1880 roku w Słupcy (obecnie woj. wielkopolskie). Był synem Edwarda i Józefy Pelagii z Lewickich. W roku 1889 rozpoczął naukę w szkole ćwiczeń przy seminarium nauczycielskim w Łęczycy. Przez rok uczył się w gimnazjum realnym w Łowiczu, jednak ostatecznie ukończył łódzką szkołę rzemieślniczą w 1898 roku³. O młodości Przanowskiego Wiktor Abroziewicz pisał w sposób następujący:

Dzieciństwo upłynęło mu w domu rodzinnym, gdzie dominował poważny stosunek do życia osobistego i czynna postawa wobec życia zbiorowego. Atmosfera starych grodów, Słupcy i Łęczycy, a zwłaszcza Łęczycy - miejsca zamieszkania rodziców Władysława Przanowskiego, gdzie jego ojciec był inżynierem powiatowym - oddziaływała bezpośrednio na kształtowanie się jego polskości. Wzmacniały ją tradycje ostatniego powstania, w którym uczestniczył ojciec Władysława. Władysław wychowywał się w polskim domu patriotycznym, w domu obcym małostkowemu bytowaniu inteligencji prowincjonalnej. Do domu rodziców Władysława przenikały ideały społeczne ówczesnego pozytywizmu, nadającego młodym Przanowskim kierunek pracy organicznej, podnoszonej w ówczesnej świadomości polskiej do godności odnowicielki bytu narodowego ${ }^{4}$.

2 W. Ambroziewicz, Wtadystaw Przanowski i jego dzieto, Warszawa 1964, s. 329.

3 S. Konarski, Przanowski Wtadystaw, w: Polski Stownik Biograficzny, t. 28, Warszawa - Wrocław 1984, s. 642-644.

4 W. Ambroziewicz, Wtadystaw Przanowski (̇̇ycie i dziatalność), „Przegląd Historyczno-Oświatowy" 1960, nr 1, s. 127-138. 
W 1899 roku rozpoczął studia na Wydziale Budowy Maszyn Szkoły Politechnicznej we Lwowie, które zwieńczył dyplomem inżyniera w roku 1906. W tym samym roku rozpoczął pracę jako nauczyciel matematyki, którą kontynuował przez następnych siedem lat. Uczył na pensji Anieli Wereckiej w Warszawie i Szkole Handlowej Zgromadzenia Kupców, również w Warszawie. W tej ostatniej placówce zetknął się z metodą kształcenia młodzieży techniką slójdu, funkcjonowała tam bowiem pracownia prowadzona przez Józefa Przyłuskiego. W roku 1913 objął kierownictwo szkoły rzemieślniczej im. Karola Szlenkiera w Warszawie i pozostawał na tym stanowisku do 1930 roku.

W tejże szkole Przanowski postanowił wprowadzić do programu roboty ręczne, przede wszystkim w zakresie obróbki drewna, widząc w tym znaczące efekty wychowawcze. Ponieważ wyniki pracy okazały się bardzo pozytywne, pojawił się projekt wprowadzenia robót ręcznych jako przedmiotu do programu szkól powszechnych. Działania te zostały zatrzymane w wyniku wybuchu I wojny światowej, jednakże nie zostały one zupełnie zaniechane, bowiem Przanowski został członkiem Komisji Pedagogicznej powołanej do życia przez Stowarzyszenie Nauczycielstwa Polskiego. Jeszcze w roku 1914 udało się plany te zrealizować i w programie szkół powszechnych znalazły się roboty ręczne w wymiarze od czterech do sześciu godzin tygodniowo. Wprowadzenie tego przedmiotu do szkół pociągało za sobą konieczność wykształcenia odpowiedniej kadry nauczycielskiej. Temu problemowi zaradzić miały uruchomione w październiku 1915 roku Roczne Kursy Robót Ręcznych. Na pierwszy kurs zgłosiło się 26 chętnych, z czego ukończyło go 21 słuchaczy. Finansowaniem tego doskonalenia zajął się Wydział Oświaty, jednakże w następnych latach Kursy borykały się z problemami finansowymi. $Z$ pomocą przyszła rada miejska Warszawy ${ }^{5}$.

Po odzyskaniu niepodległości finansowanie Kursów przejęło Ministerstwo Wyznań Religijnych i Oświecenia Publicznego, które też je upaństwowiło w roku szkolnym 1919/20. Co więcej, roboty ręczne wprowadzono także do szkół średnich i seminariów nauczycielskich, a absolwenci uzyskali prawo nauczania tego przedmiotu

5 M. Vogelsang-Soczyńska, Dziatalność Państwowego Instytutu Robót Ręcznych dla nauczycieli w okresie od 1915 do 1939 r., „Przegląd Historyczno-Oświatowy"1960, nr 1, s. 138-144. 
we wszystkich typach szkół ogólnokształcących. To upaństwowienie przyczyniło się także do otrzymania własnego lokalu, który mieścił się w gmachu szkoły im. K. Szlankiera. Zapotrzebowanie na nauczycieli tego przedmiotu ciągle rosło. W 1922 roku utworzono Państwowe Roczne Kursy Robót Ręcznych najpierw w Krakowie, potem we Lwowie i później także w Mysłowicach. Jednakże, jak pisze Maria Vogelsang-Soczyńska,

doświadczenie siedmioletniej pracy wykazało, że przygotowanie nauczycieli robót ręcznych na rocznych kursach jest niewystarczające dla szkół średnich i seminariów nauczycielskich, mimo bardzo intensywnej pracy ze strony słuchaczy i wykładowców. W związku z tym dyrekcja Kursów zwróciła się w 1923 r. do Ministerstwa Wyznań Religijnych i Oświecenia Publicznego z wnioskiem o przekształcenie rocznych kursów na trzyletnie studia, twierdząc, że dopiero wtedy będzie można przygotować całkowicie odpowiedzialnych za swą pracę nauczycieli robót ręcznych dla szkół średnich i zakładów kształcenia nauczycieli ${ }^{6}$.

Ministerstwo Wyznań Religijnych i Oświecenia Publicznego przychyliło się do tego wniosku, ale nie w całości i rozporządzeniem z dnia 14 kwietnia 1923 roku powołało do życia Państwowy Instytut Robót Ręcznych. Cykl kształcenia obejmował dwa lata ${ }^{7}$.

Rok później przy PIRR zorganizowano Wyższe Kursy Nauczycielskie, kształcące nauczycieli robót ręcznych i rysunków. Rada pedagogiczna PIRR była niezwykle aktywna na polu działalności edukacyjnej i metodycznej. Wydawano podręczniki do robót ręcznych, opiniowano programy nauczania, instruowano czynnych nauczycieli, a także redagowano i wydawano periodyk zatytułowany „Prace Ręczne w Szkole” (kwartalnik). Oprócz tego wydawano także takie czasopisma, jak „Roboty Ręczne i Rysunki” czy „Młody Technik". Rada wraz z dyrektorem Przanowskim zainicjowała powołanie do życia Towarzystwa Miłośników Robót Ręcznych, którego prezesem został Tadeusz Łopuszański. Towarzystwo to do września 1939 roku zorganizowało pięć zjazdów, które odbyły się kolejno w latach: 1926, 1929, 1931, 1935 i 1938. Miały one przede wszystkim za zadanie informowanie o działalności i dorobku To-

6 Tamże, s. 140.

7 Rozporządzenie Ministra Wyznań Religijnych i Oświecenia Publicznego z dnia 14 kwietnia 1923 r. (Dz.U. MWRiOP, 1923, nr 11, poz. 112). 
warzystwa, a także stanowiły okazję do prezentacji prac wychowanków i kursantów PIRR ${ }^{8}$.

Instytut rozrastał się coraz bardziej, przybywało nauczycieli robót ręcznych. Zaistniała wówczas potrzeba zorganizowania ognisk metodycznych robót ręcznych, które powołano w roku szkolnym 1930/31. Powstały one w Krakowie, Lwowie i Poznaniu. W sumie do roku 1939 utworzono 14 ognisk metodycznych ${ }^{9}$.

Przanowski jako dyrektor PIRR utrzymywał kontakty z placówkami zagranicznymi o analogicznych programach nauczania. W roku 1927 odbył wycieczkę do Danii, Szwecji i Niemiec, zapoznając się tam z pracą różnych szkół i realizacją przedmiotu prace ręczne. Dla słuchaczy i nauczycieli Instytutu zorganizował wyjazd studyjny do Danii. PIRR miał też swoje miejsce na prezentację dorobku na Powszechnej Wystawie Krajowej w Poznaniu w 1929 roku. Przanowski opierał się przede wszystkim na technice szwedzkiego slőjdu, ale stworzył własny, polski system kształcenia uczniów w oparciu o zdolności manualne. Uważał bowiem, że

praca ręczna nie może być traktowana jedynie jako środek kształcenia charakteru i poczucia estetycznego, ale że powinna wyrabiać określone umiejętności techniczne, kształcić zaradność. Uważał też, że uczeń tym trwalej pozna jakiś przedmiot czy zjawisko, im więcej jego zmysłów weźmie udział w tym poznawaniu. Będąc początkowo przeciwnikiem używania maszyn, uznał ich stosowanie w wyższych klasach za celowe, a w latach trzydziestych stał się rzecznikiem upowszechniania wśród starszej młodzieży szkolenia motoryzacyjnego ${ }^{10}$.

Państwowy Instytut Robót Ręcznych rozwijał się nieprzerwanie do wybuchu wojny. We wrześniu 1939 roku gmach Instytutu zajęły wojska niemieckie. Po wojnie Instytut odrodził się i działał, ale poza Warszawą. Pierwotnie, przez jakiś czas w Łodzi, a później w Bielsku. Został zlikwidowany w roku $1951^{11}$.

8 M. Vogelsang-Soczyńska, Dziatalność Państwowego Instytutu Robót Ręcznych dla nauczycieli w okresie od 1915 do 1939 r., dz. cyt., s. 140-141.

9 Tamże, s. 144-145.

10 S. Konarski, Przanowski Wtadystaw, dz. cyt., s. 644.

11 J. Łabuz, Państwowy Instytut Robót Ręcznych w Warszawie z siedzibq w Bielsku, „Przegląd Historyczno-Oświatowy” 1960, nr 1, s. 146-152. 


\section{Działalność PIRR w latach 1928-1938 w świetle protokołów rad pedagogicznych}

Pierwszy zachowany protokół pochodzi z 29 lutego 1928 roku. Już pierwszą cenną informacją płynącą z jego treści jest skład rady pedagogicznej placówki. Znajdujemy tam następujące nazwiska: Z. Andrzejewski, Z. Patkowski, M. Czechowska, H. Sadowska, M. Wojnarowicz, F. Wojnarowicz, A. Wójtów, I. Huber, P. Pietrzykowski, W. Czyżycki, W. Radwan, J. Mazurek. Nie jest to pełna lista, brakuje na niej bowiem postaci głównej, czyli dyrektora placówki, Władysława Przanowskiego, który na tym posiedzeniu był nieobecny ${ }^{12}$.

Oczywiście stan kadry ewoluował w trakcie dalszej działalności placówki. Na początku roku szkolnego 1928/29 pojawiło się trzech nowych nauczycieli w osobach Bojarnausa, Carkowskiego i Klusa ${ }^{13}$.

Z kolei na początku roku szkolnego 1933/34 stan kadry nauczycielskie stanowili: Władysław Przanowski (dyrektor), Zygmunt Andrzejewski, Maria Blomberg-Mrozowska, Nina Bobieńska, Dionizy Bojarnaus, Walenty Czyżycki, Wincenty Czerwiński, Maria Czechowska, Ignacy Huber, Stanisław Malec, Zofia Patkowska, Piotr Pietrzykowski, Feliks Wojnarowicz, Marian Wojnarowicz, Kazimierz Zacharkiewicz ${ }^{14}$.

W roku szkolnym 1937/38 do pracy przystąpiło 27 nauczycieli, łącznie z dyrektorem placówki. Wśród nich znaleźli się „starzy”, wypróbowani już pedagodzy, pracujący w Instytucie od wielu lat, oraz zupełnie nowe siły nauczycielskie. $\mathrm{Na}$ liście nazwisk znajdują

12 Archiwum Państwowe w Warszawie, Archiwum Dokumentacji Osobowej i Płacowej w Milanówku, Państwowy Instytut Robót Ręcznych w Warszawie, Księga Protokołów Państwowego Instytutu Robót Ręcznych w Warszawie, t. 2, 1928-1933, sygn. 2, Protokół Nr 11 z posiedzenia Rady Pedagogicznej Państwowego Instytutu Robót Ręcznych w dniu 29 lutego 1928 r., k. 7, (dalej odpowiednio: APW, ADOP, KPPIRR2).

13 APW, ADOP, KPPIRR2, Protokół Nr 1 z posiedzenia Rady Pedagogicznej Państwowego Instytutu Robót Ręcznych w dniu 3/9 1928 r., k. 16a.

14 Archiwum Państwowe w Warszawie, Archiwum Dokumentacji Osobowej i Płacowej w Milanówku, Państwowy Instytut Robót Ręcznych w Warszawie, Księga Protokołów Państwowego Instytutu Robót Ręcznych w Warszawie, t. 3, 1923-1939, sygn. 3, Protokół Nr 1 z posiedzenia Rady Pedagogicznej PIRR w dniu 24 sierpnia 1933 r. pod przewodnictwem p. Dyr. Wł. Przanowskiego, k. 21, (dalej odpowiednio: APW, ADOP, KPPIRR3) 
się takie osoby: Stanisław Malec (dyrektor), Zygmunt Andrzejewski, Nina Bobieńska, Dionizy Bojarnaus, Franciszek Buczkowski, Maria Czechowska, Wincenty Czerwiński, Walenty Czyżycki, Mieczysław Czyżykowski, Wiktoria Dybowska, Stanisław Gabriel, Ignacy Huber, Aleksander Ligaszewski, Adam Majewski, Maria Blomberg-Mrozowska, Zofia Patkowska, Piotr Pietrzykowski, Wacław Radwan, Józef Rafalski, Tadeusz Szadeberg, Czesław Ścisłowski, Józef Włodarski, Feliks Wojnarowicz, Marian Wojnarowicz, Władysław Wołkowski, Maria Vogelsang, Franciszek Zawadzki ${ }^{15}$.

Ważnym elementem było oczywiście kreowanie polityki edukacyjnej i wychowawczej Instytutu Robót Ręcznych. Najczęściej na pierwszych posiedzeniach rady pedagogicznej w nowym roku szkolnym opracowywano i przyjmowano do realizacji pewien plan, który miał służyć rozwojowi placówki. We wrześniu 1928 roku w tym planie znalazły się następujące punkty: „1) Przedyskutowanie podstaw metod nauczania, 2) Opracowanie i wydanie podręczników z robót ręcznych oraz kwartalnika «Praca ręczna», 3) Utrzymywanie i nawiązanie stosunków z instytucjami naukowymi za granicą, 4) Kształcenie oraz przygotowanie nowych sił do pracy w Instytucie, 5) Opracowanie nowego statutu dla Instytutu Robót Ręcznych, 6) Wybranie lub opracowanie typów narzędzi i warsztatów, 7) Przygotowanie wystawy robót ręcznych w Poznaniu, 8) Zorganizowanie zjazdu nauczycieli robót ręcznych"16.

W grudniu 1929 roku na posiedzeniu rady pedagogicznej Władysław Przanowski, dyrektor Instytutu, poinformował zebranych o projekcie wniosku skierowanego do Kuratorium Okręgu Szkolnego Warszawskiego, w którym starano się o uzyskanie prawa do hospitowania i urządzania lekcji praktycznych w niektórych szkołach na terenie Warszawy, jak choćby w seminariach nauczycielskich im. S. Konarskiego i im. E. Orzeszkowej ${ }^{17}$.

$\mathrm{Na}$ tym samym posiedzeniu rozwinęła się dyskusja nad przyszłym profilem działalności Państwowego Instytutu Robót Ręcznych. Swój

15 APW, ADOP, KPPIRR3, Rok szkolny 1937/38. Skład Rady Pedagogicznej, k. 98.

16 Tamże, k. 17.

17 APW, ADOP, KPPIRR2, Protokół 3 z posiedzenia Rady pedag. Państw. I.R.R.w dniu 11 grudnia 1929 pod przewodnictwem p. Dyr. Przanowskiego, k. 38a. 
projekt przedłożył dyrektor Przanowski, a zawierał się on w następujących słowach:

Nasza instytucja składa się z Instytutu i W.K.N. Słuchacze W.K.N. mają prawo nauczania rob. ręcz. i rysunków w szkołach powszech. Słuchacze Instytutu mają prawo nauczania rob. ręcz. i rysunków w szkołach powszechnych i rob. ręcz. w seminariach i gimnazjach. W szkołach średnich skreślono część godzin rys. i rob. ręcz. Pożądanem jest, by oba te przedmioty były w rękach jednego nauczyciela. Potrzebna jest instytucja, która by kształciła w tym kierunku i dawała odpowiednie prawa. Instytut mógłby odpowiedzieć zadaniu po pewnej reorganizacji. Studia musiałby trwać najmniej 3 lata. Po zreferowaniu sprawy w M.W.R.iO.P. po zakreśleniu programu w ogólnych zarysach, ułożeniu statutu, będzie można przystąpić do ułożenia szczegółowego programu. [...] Nauczyciele $\mathrm{w}$ ten sposób przygotowani będą mogli uczyć nawet w szkołach zawodowych ${ }^{18}$.

Jednakże niektórzy nauczyciele Instytutu wyrażali swoje obawy o to, czy możliwe jest dobre opanowanie przez słuchaczy techniki rysunku. Inni twierdzili, że przy dobrze ułożonym programie i zajęciach praktycznych jest to w zupełności do zrealizowania. Andrzejewski podkreślał, że celem PIRR jest stworzenie „idealnych pedagogów-plastyków”. Twierdzil, że „typ nauczyciela plastyki musi objąć wszystko to, co wychodzi z 3 wymiarów. W naszym Instytucie chodzi o rozwój intelektualny słuchacza, o rozwój pewnych zdolności i zamiłowanie do pracy"19. W tym ostatnim zdaniu skupiła się cała mówiąc współczesnym językiem - misja szkoły, jaką był Państwowy Instytut Robót Ręcznych w Warszawie. Ministerstwo uzależniało wprowadzenie takiego rozwiązania po uprzednim wybudowaniu nowego gmachu dla Instytutu, a to planowano zrealizować w latach późniejszych ze względu na problemy finansowe, które dotykały w tym czasie całą oświatę, co więcej Polskę - był to bowiem okres ogólnoświatowego kryzysu finansowego.

Mimo tych problemów, pracę nad statutem i programem zreorganizowanego Instytutu trwały nadal. Podczas posiedzenia rady pedagogicznej w dniu 5 marca 1930 roku dyskutowano nad projektem, a nauczyciele zgłaszali propozycje nazwy zreorganizowanej placówki. Pojawiły się takie propozycje jak: „Państwowy Instytut Artystyczno-

\footnotetext{
18 Tamże, k. 39a.

19 Tamże, k. 40.
} 
-Technicznego Kształcenia”, „Państwowy Instytut Nauczycielski Kształcenia Artystyczno-Technicznego”, „Państwowy Instytut dla nauczycieli pracy ręcznej i rysunku” czy „Państwowy Instytut Pedagogiczny dla nauczycieli rysunku i robót ręcznych"20.

Dyrekcja i nauczyciele PIRR nie zapominali również o swoich absolwentach. Przejawem tego były kursy wakacyjne, podczas których niegdysiejsi słuchacze i słuchaczki Instytutu mogli uzupełnić swoją wiedzę, dokształcić się w zagadnieniach praktycznych. Członkowie rady pedagogicznej podkreślali, że potrzeba organizowania tego typu kursów jest „kolosalna”21.

Opieką otaczano także szkoły kresowe. Jesienią 1935 roku podjęto decyzję o zorganizowaniu tygodnia szkół kresowych. Oczywiście nie było to zadanie łatwe. Pojawiało się wiele wątpliwości w jaki sposób zrealizować to przedsięwzięcie, aby osiągnąć zamierzony cel. Rozważano, czy dać tylko narzędzia bez żadnych pomocy naukowych, czy zaangażować do organizacji słuchaczy PIRR, jak zorganizować pracę w ciągu całego tygodnia? Efektem tej dyskusji były takie oto wnioski (cele): „1) ze względów wychowawczo-społecznych organizować tydzień pracy dla szkół kresowych; 2) główną uwagę zwrócić na narzędzia nie wyrzekając się wykonywania i pomocy naukowych; 3) projekt p. Kucharskiego rozpatrzeć (urządzenie loterii fantowej celem uzyskania funduszów na zakup niektórych narzędzi); 4) oraz postanowiono szczegółowiej temat tygodnia przemyśleć do najbliższego posiedzenia"22. Jednocześnie rada pedagogiczna postanowiła objąć opieką jedną ze szkół kresowych. Powołano w tym celu specjalny komitet, na czele którego stanęła Maria Czechowska.

Tydzień szkół kresowych odbył się w marcu 1936 roku. Przez pełnych sześć dni słuchacze Państwowego Instytutu Robót Ręcznych wykonywali specjalne prace, których efektem były szafki narzędziowe i pomoce dydaktyczne do nauczania różnych przedmiotów, które

20 APW, ADOP, KPPIRR2, Protokół 7 z posiedzenia Rady pedag. Państw. I.R.R. z dnia 5.III.1930 pod przewodnictwem p. Dyr. Przanowskiego, k. $46 \mathrm{a}-47$.

21 APW, ADOP, KPPIRR2, Protokół 4 z posiedzenia Rady Pedagogicznej Państw. I.R.R. w dniu 18 XII 1929 r. pod przewodnictwem p. Dyr. Przanowskiego, k. 42.

22 APW, ADOP, KPPIRR3, Protokół Nr 5 z posiedzenia Rady Pedagogicznej Państw. Instyt. Rob. Ręcz. w dniu 17 XII 1935 r., k. 68a. 
zostały przekazane szkołom na Kresach. Jak zauważono, szczególnie aktywnie i entuzjastycznie słuchacze PIRR pracowali przez pierwsze trzy dni, później nastąpiło coś w rodzaju „zmęczenia materiału”, jednakże pracy swej nie przerywali ${ }^{23}$.

Ważne miejsce w działalności szkoły zajmowały wystawy. Ta bodajże najważniejsza, była częścią Powszechnej Wystawy Krajowej, która odbyła się w roku 1929 roku w Poznaniu z okazji jubileuszu 10-lecia niepodległej Polski. Wystawie tej poświęcono posiedzenie rady pedagogicznej, które odbyło się 3 listopada 1928 roku. Podano między innymi datę otwarcia wystawy - 16 maja 1928 roku. PIRR miał się prezentować ze swoimi pracami obok innych szkół na sali o wymiarach mniej więcej 13-19 $\mathrm{m}^{2}$. Instytut miał także możliwość nagrania filmu, który w lepszy sposób niż obrazy statyczne promowałby dorobek placówki. Poza tym na koszt ministerstwa można było wykonać 10 fotografii ${ }^{24}$. Co fotografować i co filmować oraz jak urządzić salę? Te tematy dyskutowane były na posiedzeniu rady pedagogicznej w dniu 7 listopada 1928 roku $^{25}$.

Jednakże jeszcze we wrześniu tegoż roku dyrektor PIRR Władysław Przanowski poinformował swoich współpracowników o tym, że został powołany przez Ministerstwo Wyznań Religijnych i Oświecenia Publicznego do grona osób odpowiedzialnych za tę wystawę, w związku z czym otrzymał roczny urlop, by zająć się li tylko sprawami organizacyjnymi ${ }^{26}$.

Wspomnianą wyżej salę na Powszechnej Wystawie Krajowej w Poznaniu, w której miał się prezentować Państwowy Instytut Robót Ręcznych, urządzono w ten sposób, że przy ścianach wokół sali swoje eksponaty umieścili przedstawiciele szkolnictwa ogólnego. $\mathrm{Na}$ środku sali ustawiono pawilonik, w którym wewnątrz (w sześciu wnękach) postawiono stoły przeznaczone na prezentację dorobku Państwowego Instytutu Robót Ręcznych. Obok był także jeden mały pokoik, w któ-

23 APW, ADOP, KPPIRR3, Protokół Nr 9 z posiedzenia Rady Pedagogicznej P.I.R.R.w dniu 6/4 1936 r., k. 71a.

24 APW, ADOP, KPPIRR2, Protokół Nr 4 z posiedzenia Rady Pedagogicznej Państwowego Instytutu Robót Ręcznych w dniu 3 listopada 1928 r., k. 19.

25 APW, ADOP, KPPIRR2, Protokół Nr 5 z posiedzenia Rady Pedagogicznej Państwowego Instytutu Robót Ręcznych w dniu 7 listopada 1928 r., k. 20.

26 APW, ADOP, KPPIRR2, Protokół Nr 3 z posiedzenia Rady Pedagogicznej Państwowego Instytutu Robót Ręcznych w dniu 7 IX 1928 r., k. 18a-19. 
rym wyłożone zostały albumy i wydawnictwa. „Instytut będzie nadbudową szkolnictwa ogólnego. Należy więc pomyśleć w jaki sposób poszczególne działy ująć, ażeby odbijały się na terenie szkolnictwa" ${ }^{27}$.

Jeszcze w marcu 1929 roku odbyło się specjalne posiedzenie rady pedagogicznej dotyczące wystawy. Okazało się bowiem, że obok prezentacji dorobku szkół w zakresie prac ręcznych głoszone będą wykłady, stąd też nie będzie osobnej ekspozycji PIRR, a ich eksponaty stanowić będą uzupełnienie dla tych prezentowanych przez szkoły powszechne i średnie. W ten sposób chciano między innymi podkreślić dydaktyczny charakter szkoły ${ }^{28}$.

Kończąc wątek Państwowej Wystawy Krajowej w Poznaniu i udziału w niej PIRR, należy zauważyć jeszcze jeden fakt. Otóż władze placówki dbały oto, aby wszyscy uczniowie Instytutu wzięli udział w tym ważnym dla Polski przedsięwzięciu. Stąd też, gdy jesienią 1929 roku okazało się, że jeszcze grupa 30 słuchaczy PIRR nie brała udziału w wystawie poznańskiej, postanowiono specjalnie dla niej urządzić wycieczkę, której organizację powierzono dwojgu nauczycieli - Huberowi i Dybowskiej ${ }^{29}$.

Trzeba wspomnieć, że Instytut organizował także swoje wewnętrzne wystawy. Jedna z nich odbyła się w czerwcu 1931 roku. Jej otwarcie, które miało miejsce 13 czerwca, uświetnił swoją obecnością wiceminister oświaty Kazimierz Pieracki. Na wystawie prezentowane były wytwory słuchaczy PIRR, a odwiedzili ją kuratorzy (18 czerwca), inspektorzy szkolni (19 czerwca) oraz przedstawiciele Instytutu Pedagogów Słowiańskich (1-4 lipca) ${ }^{30}$.

W protokole nr 33 z 1 lipca 1931 roku zapisano, że

pan wiceminister zwiedził wystawę bardzo szczegółowo i wyraził swe całkowite zadowolenie z wyników prac. Stwierdził, że Instytut w ostat-

27 APW, ADOP, KPPIRR2, Protokół Nr 8 z posiedzenia Rady Pedagogicznej Państwowego Instytutu Robót Ręcznych w dniu 8 III 1929 r., k. 24.

28 APW, ADOP, KPPIRR2, Protokół $\mathrm{Nr} 9 \mathrm{z}$ posiedzenia Rady Pedagogicznej Państwowego Instytutu Robót Ręcznych w dniu 27 III 1929 r. w sprawie Wystawy Krajowej w Poznaniu, k. 24.

29 APW, ADOP, KPPIRR2, Protokół 2 z posiedzenia Rad. pedag. Państw. I.R.R. w dniu 7.09.1929, k. 37.

30 APW, ADOP, KPPIRR2, Protokół nr 30 (13) posiedzenia R.P. Państw. Ins. R. R. z dnia 6 czerwca b.r. [1931] odbytego pod p. Dyr. W1. Przanowskiego, k. 81 . 
nich latach bardzo się rozwinął i przyrzekł bliżej się zainteresować pracą w Instytucie w ciągu roku przyszłego. Obecny kierunek pracy w Instytucie odpowiada jego poglądom. Pozatem przyrzekł p. wicem. pomoc finansową dla Instytutu ${ }^{31}$.

Z dużym prawdopodobieństwem wystawę otwierałby ówczesny minister wyznań religijnych i oświecenia publicznego - Sławomir Czerwiński. Uniemożliwił mu to wówczas zły stan zdrowia, zresztą choroba spowodowała jego zgon w czasie wakacji - 4 sierpnia 1931 roku. Jego pamięć nauczyciele PIRR uczcili na pierwszym posiedzeniu rady pedagogicznej odbytym w dniu 1 września 1931 roku. Podkreślono także, że śmierć ministra stanowi dużą stratę nie tylko dla oświaty jako całości, ale także dla samego Instytutu, wobec którego minister Czerwiński zajmował bardzo przychylne stanowisko $^{32}$.

Wracając do tematyki wystaw, Państwowy Instytut Robót Ręcznych miał się zaprezentować w roku 1932 na wystawie w Nicei, organizowanej przez Ligę Nowego Wychowania. Wobec powyższego postanowiono zorganizować próbną wystawę na terenie szkoły, gdzie główny nacisk miał być położony na wytwory z drewna, metalu i tektury ${ }^{33}$.

$\mathrm{Z}$ protokołów rady pedagogicznej można również wywnioskować, że PIRR prowadził szeroko zakrojoną współpracę międzynarodową, a z pewnością żywo interesował tym, co działo się w innych państwa w kwestii kształcenia kadr nauczycielskich w zakresie prac ręcznych. Już w pierwszym z zachowanych protokołów jednym z punktów było omówienie wystawy, która odbyła się Pradze ${ }^{34}$.

31 APW, ADOP, KPPIRR2, Protokół nr 33 (16) posiedzenia Rady Pedagogicznej P.I.R.R. z dnia 1 lipca 1931 odbytego pod przewodnictwem p. Dyr. Wł. Przanowskiego, k. 90a.

32 APW, ADOP, KPPIRR2, Protokół Nr 34 (1) Posiedzenia Rady Pedagogicznej P.I.R.R w dniu 1 września 1931 roku odbytego pod przewodnictwem p. Dyr. Władysława Przanowskiego, k. 92.

33 APW, ADOP, KPPIRR2, Protokół 41 (8) Posiedzenia Rady Pedagogicznej P.I.R.R z dnia 11 czerwca [1932] odbytego pod przewodnictwem p. Dyrektora Władysława Przanowskiego, k. 103.

34 APW, ADOP, KPPIRR2, Protokół Nr 11 z posiedzenia Rady Pedagogicznej Państwowego Instytutu Robót Ręcznych w dniu 29 lutego 1928 r., k. 7, k. 7 . 
Z początkiem roku szkolnego 1928/29 przyjęto zasady dokonywania sprawozdań $\mathrm{z}$ wyjazdów zagranicznych członków rady pedagogicznej. Zakładały one, że poszczególni sprawozdawcy odpowiadać będą na pytania stawiane przez pozostałych nauczycieli rady pedagogicznej, a na koniec przedstawią ogólną charakterystykę odwiedzanych przez siebie zakładów. Przyjęto także harmonogram przedstawiania tych sprawozdań w danym roku szkolnym ${ }^{35}$.

Już pierwsze takie sprawozdanie pojawiło się na kolejnym posiedzeniu rady pedagogicznej, które odbyło się w dniu 5 września 1928 roku i w zasadzie w całości poświęcone było relacji z wyjazdu zagranicznego. Czytamy w nim:

Pan Dyr. Przanowski wraz z p. Huberem zdali sprawozdanie z wyjazdu do Niemiec, Danii i Szwecji. Pan Dyrektor podkreślił znaczenia wiązania kontaktów z zagranicą przez wysłanie delegacji co roku do różnych krajów oraz przez pismo, którego zeszyty są rozsyłane do wszelkich instytucji nam pokrewnych. Przygotowania poczynione przed wyjazdem w formie nawiązania korespondencji, ułatwiły bardzo podróż. Panowie zwiedzili: Instytut Pedagogiczny w Dreźnie i Lipsku, Seminarium robót ręcznych w Lipsku i Berlinie, Szkołę sztuk pięknych w Berlinie, Szkoły powszechne i średnie w Dreźnie i Lipsku, Seminarium slőjdu i szkoły powszechne w Kopenhadze, Seminarium slőjdu w Räss ${ }^{36}$.

Instytut brał udział także w krajowych zjazdach nauczycielskich. W 1929 roku zaplanowany był zjazd, organizowany przez Towarzystwo Szkół Robót Ręcznych. Odbywał się on w okolicach Zielonych Świątek i miał trwać siedem dni. Nauczycielom biorącym udział w tym zjeździe ministerstwo udzieliło urlopów ${ }^{37}$.

Mimo że w placówce kształcono dojrzałych już uczniów, nie brakowało problemów wychowawczych, w rozwiązywanie których angażowali się członkowie rady pedagogicznej. Taki epizod pojawił się na przykład w protokole z dnia 1 czerwca 1928 roku. Odnotowano go następująco: „W sprawie czynnej obrazy p. Frydelskiego przez p. Nowotnego została wyłoniona Komisja z Rady Pedagogicznej

35 APW, ADOP, KPPIRR2, Protokół Nr 1 z posiedzenia Rady Pedagogicznej Państwowego Instytutu Robót Ręcznych w dniu 3/9 1928 r., k. 16a.

36 APW, ADOP, KPPIRR2, Protokół Nr 2 z posiedzenia Rady Pedagogicznej Państwowego Instytutu Robót Ręcznych w dniu 5.IX.1928 r., k. 18.

37 APW, ADOP, KPPIRR2, Protokół Nr 8 z posiedzenia Rady Pedagogicznej Państwowego Instytutu Robót Ręcznych w dniu 8 III 1929 r., k. 24. 
składająca się z p.p. Andrzejewskiego, Radwana Wójtowa, która po dokładnem zbadaniu sprawy, udzieliła p. Nowotnemu surowej nagany"38.

Naganę z wpisem do księgi uczniów otrzymali także słuchacze, którzy samowolnie opuścili zajęcia przed świętami Bożego Narodzenia 1932 roku. Działalnie rady pedagogicznej z jednej strony miało charakter represyjny - ukarano winnych złamania regulaminu, z drugiej zaś prewencyjny - chciano w ten sposób odstraszyć innych od podobnych występków ${ }^{39}$.

Starano się także wpływać na wychowanie młodzieży, w tym również to estetyczne czy kulturalne. Na terenie Instytutu działał teatr. Zagadnienie to miało niebawem pojawić się jako jeden z zakresów „pracy słuchaczów Instytutu, którzy mają zapoznać się z techniką urządzania możliwie najróżnorodniejszych imprez szkolnych, jak teatr, widowiska, szopka, jasełka, kukiełki, obchody uroczystości, itd.” ${ }^{40}$. Kwestia ta miała się znaleźć także w zakresie organizowanych wystaw.

$Z$ pewnością za element wychowawczy należy uznać obchody imienin dostojników państwowych, w tym oczywiście marszałka Józefa Piłsudskiego. W marcu 1935 roku (imieniny marszałka przypadały na 19 marca) dyrektor Przanowski zaproponował inny scenariusz tychże obchodów. Zasugerował, aby odstąić od deklamacji wierszy i śpiewu pieśni i piosenek, a w to miejsce zorganizować wystawę prac słuchaczy II kursu. Proponował również wręczenie nagród za najlepiej wykonane eksponaty. Środki na nagrody w wysokości 300 zł wyasygnowało Towarzystwo Miłośników Robót Ręcznych ${ }^{41}$.

Tego samego roku słuchacze Instytutu wraz z gronem pedagogicznym jeszcze raz oddali hołd marszałkowi Piłsudskiemu. Miało to miejsce na wiadomość o jego śmierci w dniu 12 maja 1935 roku. W placówce odbyły się uroczystości żałobne, których przebieg na posiedzeniu rady pedagogicznej zrelacjonował następująco Władysław Przanowski:

Dnia 13-go maja o godzinie 8-mej rano zgromadzili się słuchacze Instytutu wraz z gronem nauczycielskim w sali rysunkowej i Dyrektor odczytał

38 APW, ADOP, KPPIRR2, Protokół Nr 13 z posiedzenia Rady Pedagogicznej Państwowego Instytutu Robót Ręcznych w dniu 1 czerwca 1928 r., k. 9 a.

39 APW, ADOP, KPPIRR3, Protokół nr 48 Posiedzenia Rady Pedagogicznej P.I.R.R. z dnia 18 stycznia [1933] odbytego pod przewodnictwem Pana Dyrektora Władysława Przanowskiego, k. 9a.

40 APW, ADOP, KPPIRR3, Protokół Nr 4. Dnia 6 listopada 1934 r., k. 48.

${ }^{41}$ APW, ADOP, KPPIRR3, Protokół 6. Dnia 6-go lutego [1935], k. 52. 
orędzie Prezydenta do Narodu. Nastąpiła długa chwila cieszy i skupienia, i słuchacze w bardzo podniosłym i smutnym nastroju udali się do pracy. Słuchaczki udekorowały żałobnie wszystkie portrety Marszałka znajdujące się w Instytutu oraz flagi narodowe, które zawieszono przed i na gmachu. Dnia 14-go maja odczytana została odezwa p. ministra oświaty do młodzieży. W myśl wskazań Ministra, wyrażonych w odezwie, lekcje w Instytucie nie zostały przerwane. Dnia 15-go maja lekcje zostały zawieszone o dwie godziny wcześniej i o godzinie 4-tej popołudniu słuchacze Instytutu wraz z gronem nauczycielskim Instytutu zebrali się wraz z całym nauczycielstwem miasta Warszawy na podwórzu Związku Nauczycielskiego i po wysłuchaniu okolicznościowego przemówienia prezesa Rosińskiego wzięli udział w pochodzie do Belwederu zorganizowanym przez Związek. Dnia 17-go maja cały Instytut o godzinie 81/2 wyruszył na Pole Mokotowskie, aby tam ostatni raz oddać hołd pamięci Marszałka. W dniu 18 maja, t.j. w dzień pogrzebu słuchacze otrzymali polecenie udania się w rannych godzinach do kościołów w celu wysłuchania mszy żałobnych ${ }^{42}$.

Równocześnie rada uchwaliła przekazanie kwoty 200 zł na usypanie kopca im. marszałka Piłsudskiego w Krakowie.

Gros uwagi w protokołach poświęcano sprawom związanym z egzaminami wstępnymi, jak i semestralnymi czy końcowymi. Czasami rada pedagogiczna podejmowała konkretne decyzje w tym zakresie, mające istotny wpływ na oceny końcowe słuchaczy Instytutu. Oto jeden z przykładów podjętego przez ciało pedagogiczne placówki wniosku dotyczącego konstruowania ocen końcowych:

Na wniosek Przewodniczącego Rada Pedagogiczna przy dokonywaniu ocen końcowych postanowiła: jeśli w wynikach rocznych wypada jedna nota dostateczna $z$ przedmiotów zasadniczych jak: roboty kobiece, kompozycja rob. kob., egzamin piśmienny, metodyka (dla grupy żeńskiej) oraz z drzewa, tektury, metalu, pomocy nauk. egzamin piśmienny (dla grupy męskiej), wówczas słuchaczka względnie słuchacz nie może otrzymać świadectwa z ogólną oceną bardzo dobrą, ale dobrą, chociażby miał z poszczególnych przedmiotów większość stopni bardzo dobrych ${ }^{43}$.

Trzeba również zauważyć, że władze szkoły w wielu kwestiach szły uczniom na rękę. $\mathrm{Na}$ przykład na początku roku szkolnego, we wrześniu 1928/29, na dwa dni zwolniono uczniów od zajęć szkolnych, aby mogli spokojnie pozałatwiać swoje osobiste sprawy. Do

42 APW, ADOP, KPPIRR3, Protokół z posiedzenia Rady Pedagogicznej Instytutu Robót Ręcznych, które odbyło się 18-go maja r.b. [1935], k. 56.

43 APW, ADOP, KPPIRR2, Protokół Nr 18 z posiedzenia Rady Pedagogicznej Państwowego Instytutu Robót Ręcznych w dniu 14 czerwca 1928 r., k. 13. 
tych spraw zaliczano między innymi wynajęcie mieszkania, tym bardziej, że gros słuchaczy i słuchaczek pochodziło spoza Warszawy ${ }^{44}$.

Jednak problemy z przystąpieniem do egzaminów miały osoby, które wykazywały się znaczącą absencją. $\mathrm{Na}$ przykład w czerwcu 1929 roku problemy z przystąpieniem do egzaminów miała jedna ze słuchaczek, której nieobecność osiągnęła poziom 15\% opuszczonych zajęć. Pojawił się także inny problem ze słuchaczką, która ze względów zdrowotnych również opuściła dużą liczbę godzin. W obu przypadkach były to uczennice I roku. Stąd też przyjęto wówczas wniosek, który pozwalał skreślić z listy słuchaczy I kursu osobę, która przekroczyła pięćdziesięcioprocentowy próg absencji. Mogła ona jednak ponownie przystąpić do egzaminu wstępnego do Instytutu ${ }^{45}$.

Z kolei jeśli chodzi o słuchaczy i słuchaczki II roku kursu, to zobowiązani byli oni zdać egzamin pisemny. Na koniec roku szkolnego 1928/29 zaproponowano takie oto tematy: „1. Stosunek całokształtu nauki rysunków do robót ręcznych i innych przedmiotów; 2. Kierunki nauczania robót ręcznych w Polsce i zagranicą od chwili wprowadzenia aż do obecnych czasów; 3. Przykład lekcji robót ręcznych na temat dowolny" 46 .

Równie ważne kwestie dotyczyły spraw organizacyjnych. Szczególnie żywo dyskutowano problem szkoły ćwiczeń im. Karola Szlenkiera. Była bowiem propozycja przeniesienia jej do innego gmachu, przeznaczonego dla szkoły miejskiej, jednakże nie zostało to zrealizowane $z$ powodu braku odpowiednich budynków. Przewodniczący zebrania uważał, że szkoły ćwiczeń nie należy się z tej placówki wyzbywać. Według niego przemawiały za tym następujące argumenty:

1. Słuchacze i czki przychodzą do nas ze szkół średnich, w których nie otrzymali metody nauczania. W szkole ćwiczeń widzą roboty dobrze prowadzone. Hospitacje i lekcje próbne w innych szkołach sprawiałyby wiele trudności, 2. Szkoła ćwiczeń na swój specjalny program robót ręcznych i rysunków o zwiększonej liczbie godzin. Piętno nauki robót zarządza się na innych przedmiotach, 3 . Szkoła posiada duży zbiór po-

44 APW, ADOP, KPPIRR2, Protokół Nr 1 z posiedzenia Rady Pedagogicznej Państwowego Instytutu Robót Ręcznych w dniu 3/9 1928 r., k. 17.

45 APW, ADOP, KPPIRR2, Protokół Nr 11 z posiedzenia Rady Pedagogicznej Państwowego Instytutu Robót Ręcznych w dniu 9 VI 1929 r., k. 27.

46 APW, ADOP, KPPIRR2, Protokół Nr 12 z posiedzenia Rady Pedagogicznej Państwowego Instytutu Robót Ręcznych w dniu 10 VI 1929 r., k. 28. 
mocy naukowych, którego w szkole dwuczasowej nie można należycie wykorzystać, 4 . Dobrany personel nauczycielski ${ }^{47}$.

Szkoła ćwiczeń została jednakże przeniesiona na ul. Gostyńską. Dla PIRR było to dość korzystne mimo wszystko posunięcie, bowiem dzięki temu zyskał on większą przestrzeń lokalową dla własnej egzystencji. Szkoła ćwiczeń nadal była integralną częścią Instytutu. Członkowie rady złożyli podziękowania dyrektorowi Przanowskiemu i jego zastępcy - Andrzejewskiemu za wkład włożony w rozwój placówki. Słowa uznania wyrazili także wobec tych osób w ministerstwie wyznań religijnych i oświecenia publicznego, które doceniają Państwowy Instytut Robót Ręcznych i dbają o jego rozwój ${ }^{48}$. Jednakże wiosną 1930 roku szkoła ćwiczeń została ponownie przeniesiona, a tym samym PIRR utracił tę przydatną dla siebie placówkę ${ }^{49}$.

W czerwcu 1929 roku wniesiono na radę pedagogiczną problem długości trwania kursu. Kuratorium uznało bowiem, że taki zakres materiału i zajęć praktycznych nie da się opanować w dwa lata, wobec powyższego przygotowywany był nowy statutu dla Instytutu, który zakładał wydłużenie okresu nauki o rok, czyli do trzech lat ${ }^{50}$.

Z kolei na początku roku szkolnego 1932/33 pojawił się inny bardzo poważny problem, który w protokole opisano następująco:

Nowy rok szkolny wysuwa przez nauczycielami robót ręcznych specjalne zagadnienia do zrealizowania. W związku z ogólną trudną sytuacją finansową, dążyć musimy do tego, by przedmioty wykonywane w pracowni miały zastosowanie praktyczne w domu i szkole oraz by modele były tak obmyślone, ażeby przy skromnie wyposażonej pracowni w dodatkowe przyrządy pomocnicze, można je było na terenie szkoły wykonać. Pan Dyr. prosił wykładających, ażeby w pracowniach mniej wymagano rys. technicznych, opierając się głównie na rysunkach roboczych dostosowanych do potrzeb pracowni ${ }^{51}$.

47 APW, ADOP, KPPIRR2, Protokół Nr 6 z posiedzenia Rady Pedagogicznej Państwowego Instytutu Robót Ręcznych w dniu 1 XII 1928 r., k. 21.

48 APW, ADOP, KPPIRR2, Protokół 1 z posiedzenia Rad. pedag. Państw. I.R.R. w dniu 2/IX 1929, k. 35a.

49 APW, ADOP, KPPIRR2, Protokół 9 z posiedzenia Rady pedagogicznej P.I.R.R.w dniu 12.IV.1930 pod przewodnictwem p. Dyr. Przanowskiego, k. 49.

50 APW, ADOP, KPPIRR2, Protokół Nr 14 z posiedzenia Rady Pedagogicznej w dniu 14 VI 1929 r., k. 29a.

51 APW, ADOP, Państwowy Instytut Robót Ręcznych w Warszawie, Księga Protokół, tom II, sygn. 3, Protokół nr 45 Posiedzenia Rady Pedagogicznej 
Trzeba także podkreślić, że protokoły rad pedagogicznych posłużyć mogą do badań genealogicznych. Szczególnie jeśli weźmie się pod uwagę te sporządzane w czerwcu każdego roku. Znajdują się w nich wykazy słuchaczy, którzy zdali egzaminy (wraz z ocenami), jak i tych, którzy zostali przyjęci do Instytutu po pomyślnie zdanych egzaminach wstępnych.

Warto wspomnieć również inną, ciekawą kwestię związaną ze sztandarem szkoły. $\mathrm{Na}$ posiedzeniu w dniu 7 grudnia 1932 roku dyrektor poinformował nauczycieli, że jest szansa na otrzymanie 1000 zł na sztandar dla Instytutu. Warunek do spełniania był jednakże jeden. Sztandar ten musiał w całości być zaprojektowany i wykonany w Państwowym Instytucie Robót Ręcznych ${ }^{52}$.

Jako twórca Instytutu, dyrektor Przanowski był mu całym sobą oddany. Nic więc dziwnego, że ciosem dla instytucji była jego niespodziewana śmierć w roku 1937. Wydarzenie to znalazło swoje odbicie, co zrozumiałe, także na kartach protokołów z posiedzeń rad pedagogicznych. W dniu 10 lutego 1937 roku na porządku dziennym posiedzenia znalazły się takie kwestie, jak treść pisma ś.p. Władysława Przanowskiego, sprawa mszy św. za duszę zmarłego, krzyż na mogile, nadanie Państwowemu Instytutowi Robót Ręcznych imienia Władysława Przanowskiego, „obstalowanie” portretu Przanowskiego, organizacja akademii ku czci zmarłego, a także poświęcenie jego osobie kwartalnika „Praca ręczna w szkole” ${ }^{\text {33 }}$.

Do protokołu z tejże rady został dołączony (wklejony do protokolarza) wniosek jednego z nauczycieli i zarazem członków rady pedagogicznej o następującej treści:

Proszę Szanownego Pana o poddanie dyskusji na najbliższym posiedzeniu Rady Pedagogicznej następujących wniosków: 1. Rada Pedagogiczna Państwowego Instytutu Robót Ręcznych w uznaniu wiekopomnych zasług wskrzeszenia przez ś.p. Władysława Przanowskiego idei Komisji Edukacji Narodowej szerzenia w wychowaniu państwowym kultu dla pracy fizycznej, postanawia zwrócić się do Pana Ministra W.R. i O.P.,

P.I.R.R w dni 6 września [1932], odbytego pod przewodnictwem Pana Dyr. Władysława Przanowskiego, k. 4. (dalej: APW, ADOP, KPPIRR3).

52 APW, ADOP, KPPIRR3, Protokół Nr 47 Posiedzenia Rady Pedagogicznej P.I.R.R. z dnia 7 grudnia [1932], odbytego pod przewodnictwem Pana dyr. Władysława Przanowskiego, k. 8.

53 APW, ADOP, KPPIRR3, Protokół Nr 5 z posiedzenia Rady Pedagogicznej odbytego 10 lutego 1937 r. pod przewodnictwem p. Z. Andrzejewskiego, k. 83a. 
aby zechciał przychylić się do najgorętszych życzeń Rady Pedagogicznej oraz wychowanków Państwowego Instytutu Robót Ręcznych i mocą swej władzy nadał tej instytucji imię jej twórcy Władysława Przanowskiego; 2. Rada Pedagogiczna postanawia w gmachu Instytutu na honorowym miejscu powiesić portret ś.p. Władysława Przanowskiego i powierza wykonanie tej uchwały komisji złożonej z przedstawicieli grona nauczycielskiego i słuchaczy Instytutu; 3. Rada Pedagogiczna Państwowego Instytutu Robót Ręcznych postanawia po porozumieniu się z Towarzystwem Miłośników Robót Ręcznych oraz ugrupowaniami nauczycieli robót ręcznych całej Polski powołać Komitet ufundowania tablicy pamiątkowej i wmurowania jej na zewnętrznej stronie gmachu, w którym żył i działał ś.p. Władysław Przanowski. Proszę o wciągniecie powyższych wniosków do protokołu posiedzeń Rady Pedagogicznej. Aleksander Ligaszewski, członek Rady Ped. P.I.R.R. ${ }^{54}$.

Wszystkie te wnioski były konsekwentnie realizowane w następnych miesiącach zarówno przez członków rady pedagogicznej, jak i przez członków Towarzystwa Miłośników Robót Ręcznych.

\section{Podsumowanie}

Powyższe rozważania można uznać za uzupełnienie dotychczasowej wiedzy o Państwowym Instytucie Robót Ręcznych działającym w okresie II Rzeczpospolitej. Choć nie są one wyczerpujące, to jednak mogą stanowić punkt wyjścia do dalszych badań w tym zakresie. Ich podstawą powinna być cała spuścizna PIRR przechowywana w archiwum w Milanówku. Dzięki dogłębnej analizie zgromadzonego tam materiału możliwe będzie między innymi dokonanie charakterystyki słuchaczy Instytutu.

\section{Bibliografa}

\section{Źr ódła}

Archiwum Państwowe w Warszawie, Archiwum Dokumentacji Osobowej i Płacowej w Milanówku, Państwowy Instytut Robót Ręcznych w Warszawie, Księga Protokołów Państwowego Instytutu Robót Ręcznych w Warszawie, t. 2, 1928-1933, sygn. 2.

Księga Protokołów Państwowego Instytutu Robót Ręcznych w Warszawie, t. 3, 1923-1939, sygn. 3.

54 Tamże. 


\section{A k ty prawne}

Rozporządzenie Ministra Wyznań Religijnych i Oświecenia Publicznego z dnia 14 kwietnia 1923 r. (Dz.U. MWRiOP, 1923, nr 11, poz. 112).

\section{0 pracowania}

Ambroziewicz W., Wtadystaw Przanowski (̇̇ycie i dziatalność), „Przegląd Historyczno-Oświatowy" 1960, nr 1.

Ambroziewicz W., Wtadystaw Przanowski i jego dzieto, Państwowe Zakłady Wydawnictw Szkolnych, Warszawa 1964.

Choińska E., Z dziejów oświaty w Polsce. Państwowy Instytut Robót Ręcznych (1923-1950), Instytut Badań Edukacyjnych, Warszawa 1998.

Konarski S., Przanowski Wtadystaw, w: Polski Stownik Biograficzny, t. 28, Polska Akademia Nauk - Zakład Narodowy im. Ossolińskich, Warszawa - Wrocław 1984.

Łabuz J., Państwowy Instytut Robót Ręcznych w Warszawie z siedzibq w Bielsku, „Przegląd Historyczno-Oświatowy” 1960, nr 1.

Vogelsang-Soczyńska M., Dziatalność Państwowego Instytutu Robót Ręcznych dla nauczycieli w okresie od 1915 do 1939 r., „Przegląd Historyczno-Oświatowy" 1960, nr 1.

\section{ADRES DO KORESPONDENCJI}

Dr hab. Piotr Gołdyn, prof. UAM

Uniwersytet im. Adama Mickiewicza w Poznaniu

Wydział Pedagogiczno-Artystyczny w Kaliszu, Zakład Pedagogiki

piotr.goldyn@amu.edu.pl 